\title{
PIJAT BAYI CARA INDIA DAN JOHNSON MENINGKATKAN BERAT BADAN BAYI BERAT LAHIR RENDAH
}

\author{
Asmawati Gasma ${ }^{\bowtie}$, Indriani Amin, Ros Rahmawati \\ Jurusan Kebidanan Poltekkes Kemenkes Makassar
}

\begin{tabular}{l} 
ARTICLE INFO \\
\hline Article history \\
Submitted : 2021-06-25 \\
Revised : 2021-12-08 \\
Accepted : 2021-12-27 \\
Keywords: \\
Indian baby massage \\
Johnson's baby massage \\
Low Birth Weigt Baby
\end{tabular}

\section{Kata Kunci:}

Pijat bayi india Pijat bayi johnson $B B L R$

\begin{abstract}
Low birth weight infant mortality is one of the causes of high infant mortality (AKB) in Indonesia. Infant mortality can be prevented by improving the quality of the baby's health through growth and development. One of the efforts to improve the quality of baby health. The study aims to prove the difference in BBLR BB increase through Indian and Johnson way baby massage. The method used is Quasy Experimen with pretest-posttes design. The population is a low birth weight baby born in RSIA Pertiwi Makassar period July - September 2018. The study sample numbered fourteen that met the criteria. Seven babies were massaged the Indian way and seven babies were massaged johnson's way. Massage is done twelve times at intervals three times a week. Fifteen minutes at a time. The instruments used are baby scales and observation sheets. Univariate data analysis showed the average increase in BB for Indian way baby massage was fifty-one percent, while theaverage weight gain for Johnson's way of baby massage was fifty-three percent. Statistical tests with mann-Whitney U, showed that there was no significant difference in BBLR BB increases between indian and johnson massage. The conclusion of this study is the indian and Johnson way baby massage can both increase BB BBLR.
\end{abstract}

\begin{abstract}
Kematian bayi berat lahir rendah merupakan salah satu penyebab tingginya angka kematian bayi (AKB) di Indonesia. Kematian bayi dapat dicegah dengan meningkatkan kualitas kesehatan bayi melalui tumbuh kembang. Salah satu upaya peningkatan kualitas kesehatan bayi. Penelitian ini bertujuan untuk membuktikan perbedaan peningkatan BB BBLR melalui pijat bayi cara India dan Johnson. Metode yang digunakan adalah Quasy Experimen dengan rancangan pretest-posttes design. Populasi adalah Bayi berat lahir rendah yang lahir di RSIA Pertiwi Makassar periode Juli September 2018. Sampel penelitian berjumlah empat belas yang memenuhi kriteria. Tujuh bayi dipijat dengan cara India dan tujuh bayi dipijat dengan cara Johnson. Pemijatan dilakukan sebanyak dua belas kali dengan interval tiga kali seminggu. Lama pemijatan lima belas menit setiap kali. Instrumen yang digunakan adalah timbangan bayi dan lembar observasi. Hasil analisis data secara univariat menunjukkan rata-rata peningkatan BB untuk pijat bayi cara India yaitu lima puluh satu persen, sedangkan rata-rata peningkatan berat badan untuk pijat bayi cara Johnson adalah lima puluh tiga persen. Uji statistik dengan mann-Whitney $U$, menunjukkan bahwa tidak ada perbedaan yang signifikan peningkatan BB BBLR antara pijat cara India dan Johnson. Kesimpulan penelitian ini adalah Pijat bayi cara India dan Johnson keduanya dapat meningkatkan BB BBLR.
\end{abstract}

\section{Corresponding Author:}

Asmawati Gasma

Jurusan Kebidanan Poltekkes Kemenkes Makassar

Telp. 081222456220

Email: asmawati_gasma@poltekkes-mks.ac.id

\section{PENDAHULUAN}

Kematian bayi di bawah lima tahun (balita) di Indonesia mencapai 28.158 Jiwa pada tahun 2020. Terdapat 20.266 (71.97\%) kematian bayi 0 - 28 hari atau neonatal, pada umumnya kematian bayi atau neonatal karena BBLR (BPS, 2020).

Penyebab kematian bayi diantaranya adalah akibat cacat lahir, kelahiran prematur dan bayi berat lahir rendah (BBLR), komplikasi kehamilan serta sindrom kematian bayi mendadak tanpa diketahui penyebabnya, penyebab lainnya yaitu kecelakaan atau luka yang tidak disengaja, infeksi saluran pernapasan bawah, komplikasi infeksi tali pusat, dan sepsis bakteri.

Untuk mencegah penyebab tersebut di atas, berbagai upaya telah dilakukan oleh 
pemerintah baik lintas program maupun lintas sektoral. Salah satu upaya adalah meningkatkan status kesehatan bayi melalui pemantauan tumbuh kembang bayi secara dini. Upaya meningkatkan berat badan bayi adalah dengan melakukan pijat bayi di beberapa Rumah Sakit Ibu dan Anak.

Hasil penelitian telah terbukti bahwa pijat bayi dapat meningkatkan kualitas tidur dan peningkatan berat badan bayi. Berdasarkan hasil penelitian bayi berat lahir rendah yang di pijat, dengan prosedur $3 \times 15$ menit selama 10 hari dapat meningkatkan berat badan per hari $20-47$ persen (Proverawati, 2010).

Hasil Penelitian (Gasma, 2016) Pengaruh Pijat Bayi terhadap peningkatan Berat badan Bayi BBLR Golongan darah "O". Terbukti secara signifikan dapat meningkatkan BB BBLR 50 - 65\% setelah pemijatan 30 kali. Namun tidak ada perbedaan kenaikan BB menurut jenis kelamin.

Studi pendahuluan akhir tahun 2017 bahwa jumlah kelahiran di RSIA Pertiwi 1.441 dan BBLR sejumlah 69 (4.79\%). Angka ini sangat tinggi. Sehingga diperlukan pencegahan yaitu meningkatkan kualitas hidup BBLR melalui pijat bayi.

Berdasarkan latar belakang tersebut, maka peneliti akan melakukan pijat bayi cara India dibandingkan dengan cara Johnson, sehingga dapat menentukan cara apa yang paling efektif untuk mempertahankan dan meningkatkan berat badan bayi baru lahir dengan BBLR.

\section{METODE PENELITIAN}

\section{Jenis Penelitian}

Jenis penelitian yang digunakan ialah Quasi Eksperimen. Rancangan penelitian PretestPosttest design. Populasi adalah BBLR yang lahir di RSIA Pertiwi Makassar periode Juli - 1 September 2018. Pengukuran dilakukan sebelum dan sesudah pemijatan yaitu 12 kali. Uji statistik digunakan mann-Withney U untuk menguji perbedaan pengaruh pijat bayi tersebut.

\section{Lokasi dan Waktu Penelitian}

Penelitian ini berlokasi di RSIA Pertiwi. Penelitian dilaksanakan pada bulan Juli Oktober 2018

\section{Populasi dan Sampel}

Populasi pada Penelitian ini adalah BBLR yang lahir di RSIA Pertiwi dan berdomisili di
Makassar periode Juli sampai 1 September 2018 sebanyak 23 minum hanya ASI dan BB 1.800 - 2.449 gram. Besar sampel ditentukan dengan menggunakan rumus besar sampel data kontinyu (Sastroasmoro \& Ismael, 2016). Berdasarkan rumus tersebut, maka diperoleh sampel sejumlah 7. Sampel penelitian dipilih secara acak berjumlah 14 sampel. Kemudian dilakukan maching agar seimbang antara kelompok A dan kelompok B. Variabel yang diteliti yaitu Varibel Independen adalah pijat bayi cara India dan Johnson sedangkan variabel dependen adalah Berat badan BBLR.

\section{Pengumpulan Data \\ Pengumpulan data yang digunakan dalam penelitian ini adalah data primer dimana data yang diperoleh langsung dari petugas dan hasil pemeriksaan fisik. Kemudian Bayi ditimbang setelah 30 hari sebagai pre test dan post test setelah dipijat sebanyak 12 kali. Instrumen penelitian yang digunakan ialah timbangan bayi dan lembar observasi.}

\section{Pengolahan dan Penyajian Data}

Pengolahan dan penyajian data dilakukan menggunakan komputer dengan program aplikasi SPSS for windows versi 21.0 melalui tahapan pengeditan, pemberian kode, penginputan, dan yang terakhir adalah tabulasi. Penyajian data disajikan dalam bentuk tabel distribusi frekuensi dan tabel analisa pengaruh antar variabel independen dan variabel dependen.

\section{Analisis Data}

Teknik analisis data yang digunakan dalam penelitian ini adalah analisis univariat untuk perhitungan nilai rerata dan standar deviasi. Selanjutnya dilakukan analisis bivariat yaitu analisis perbandingan dengan menggunakan Uji Mann-Whithney U. Tingkat kemaknaan atau signifikan; 5\%, daerah kritis: tolak $H o$ jika $\alpha=$ $0,05>$ sig, dan $H 1$ ditolak $\alpha=0,05$ <sig. (2tailed).

\section{HASIL PENELITIAN \\ Analisis Univariat \\ Penelitian ini dilaksanakan pada tanggal 6 Agustus - 31 Oktober 2018. Data kelahiran bayi dikumpulkan mulai bayi lahir 8 Juli - 1 September 2018 yang dirawat di ruang bayi RSIA Pertiwi. Kemudian dilanjutkan pemantauan hingga BBLR keluar RS. Jumlah}


subyek adalah masing-masing 7 (tujuh) tiap kelompok yang memenuhi kriteria Inklusi.
Distribusi subyek dapat dilihat pada tabel berikut:

Tabel 1. Distribusi Bayi Berat Lahir Rendah sebagai Subyek Penelitian yang Lahir di RSIA Pertiwi

\begin{tabular}{|c|c|c|c|c|}
\hline Subyek & $\mathbf{J} / \mathbf{K}$ & BBL Gram & BB pre-test 30 hari & BB post-test 60 hari \\
\hline Bayi A- & $\mathrm{P}$ & 2150 & 2300 & 3400 \\
\hline Bayi B* & $\mathrm{L}$ & 2200 & 2300 & 3800 \\
\hline Bayi C- & $\mathrm{L}$ & 2150 & 2200 & 3450 \\
\hline Bayi D* & $\mathrm{P}$ & 2100 & 2280 & 3640 \\
\hline Bayi E- & $\mathrm{P}$ & 1800 & 1900 & 2600 \\
\hline Bayi $\mathrm{F}^{*}$ & $\mathrm{~L}$ & 1900 & 2010 & 3400 \\
\hline Bayi G- & $\mathrm{L}$ & 2400 & 2490 & 3700 \\
\hline Bayi H* & $\mathrm{P}$ & 2400 & 2480 & 3600 \\
\hline Bayi I- & $\mathrm{P}$ & 2000 & 2150 & 3650 \\
\hline Bayi J* & $\mathrm{L}$ & 2300 & 2450 & 3700 \\
\hline Bayi K- & $\mathrm{L}$ & 1900 & 1850 & 2600 \\
\hline Bayi L* & $\mathrm{P}$ & 1800 & 2000 & 3400 \\
\hline Bayi M- & $\mathrm{L}$ & 1500 & 1800 & 2800 \\
\hline Bayi N* & $\mathrm{P}$ & 1500 & 1800 & 2500 \\
\hline
\end{tabular}

Berdasarkan Tabel 1 dapat terlihat bahwa dari 14 BBLR terdiri dari jenis kelamin laki-laki 7 subyek dan jenis kelamin perempuan
7 subyek, BB pre-test setelah 12 kali pemijatan (3 kali seminggu).

Tabel 2. Distribusi Frekuensi Subyek berdasarkan Peningkatan BB Setelah 12 Kali Pemijatan (Post-Test)

\begin{tabular}{ccccccc}
\hline Subyek & J/K & BBL Gram & $\begin{array}{c}\text { BB pre-test } \\
\text { 30 hari }\end{array}$ & $\begin{array}{c}\text { BB post-test } \\
\text { 60 hari }\end{array}$ & $\begin{array}{c}\text { Selisih BB } \\
\text { Gram }\end{array}$ & $\begin{array}{c}\text { \% Kenaikan } \\
\text { BB }\end{array}$ \\
\hline Bayi A & P & 2150 & 2300 & 3400 & 1100 & 47 \\
Bayi B* & L & 2200 & 2300 & 3800 & 1500 & 65.22 \\
Bayi C & L & 2150 & 2200 & 3450 & 1250 & 56.81 \\
Bayi D* & P & 2100 & 2280 & 3640 & 1360 & 59.65 \\
Bayi E & P & 1800 & 1900 & 2600 & 700 & 36.84 \\
Bayi F* & L & 1900 & 2010 & 3400 & 1390 & 69.15 \\
Bayi G & L & 2400 & 2490 & 3700 & 1210 & 47.79 \\
Bayi H* & $\mathrm{P}$ & 2400 & 2480 & 3600 & 1120 & 45.16 \\
Bayi I & $\mathrm{P}$ & 2000 & 2150 & 3650 & 1500 & 69.77 \\
Bayi J* & $\mathrm{L}$ & 2300 & 2450 & 3700 & 1250 & 51 \\
Bayi K & $\mathrm{L}$ & 1900 & 1850 & 2600 & 750 & 40.54 \\
Bayi L* & $\mathrm{P}$ & 1800 & 2000 & 3400 & 1400 & 41.17 \\
Bayi M & $\mathrm{L}$ & 1500 & 1800 & 2800 & 1000 & 55.56 \\
Bayi N* & $\mathrm{P}$ & 1500 & 1800 & 2500 & 700 & 38.89 \\
\hline Sumber: Data Primer & & \multicolumn{5}{c}{}
\end{tabular}

Berdasarkan data pada tabel 2 terlihat Berat Badan BBLR saat lahir dan setelah usia 30 hari. Berdasarkan tabel di atas, maka terlihat bahwa kelompok A yaitu Pijat cara Johnson, rata-rata BB BBLR saat lahir yaitu 2.028 gam.
Berat badan BBLR usia 30 hari saat pretest rata-rata 2.188 gram. Setelah dipijat 12 kali atau usia 60 hari, maka rata-rata BB BBLR 3.362 gram. Dengan demikian peningkatan BB setelah dipijat rata-rata 1.174 gram (53.66\%). 
Untuk kelompok B Pijat cara India, rata-rata BBL 1.986 gram, usia 30 hari rata-rata 2.098 gram. Setelah dipijat 12 pada usia 60 hari maka BB BBLR mencapai rata-rata 3.171 gram. Peningkatan BB setelah dipijat ratarata 1.073 gram $(51.14 \%)$.

\section{Analisis Bivariat}

Berdasarkan hasil uji statistik, maka hipotesis ditolak, bahwa pijat cara India dengan Johnson tidak ada perbedaan peningkatan BB secara signifikan terhadap peningkatan berat badan bayi setelah dipijat 12 kali pemijatan selama 30 hari.

\section{PEMBAHASAN}

Manfaat yang dapat diperoleh dari pijat bayi terutama pada bayi BBLR adalah penurunan kadar cotecolamin (stress), Penurunan jumlah dan sitotoksitas dari sistem imun (sel pembunuh alami/natular killer cells), Memperbaiki sirkulasi darah dan pernapasan, merangsang fungsi pencernaan serta pembuangan, membuat tidur lelap, mengurangi rasa sakit (pegal-pegal), mengurangi kembung dan colik, meningkatkan poduksi ASI, meningkatkan hubungan kasih sayang orang tua dan bayi (bonding).

Hasil telaah bahwa rata-rata peningkatan $\mathrm{BB}$ dengan pijat cara India yaitu $51,14 \%$, sedangkan peningkatan BB pijat cara Johnson yaitu $53.66 \%$. Peningkatan BB secara normal pada bayi usia $1-2$ bulan adalah 900 gram. Namun hasil penelitian ini memberikan peningkatan lebih dari standar yaitu antara 1.073 - 1.174 gram. Hasil tersebut sesuai dengan hasil penelitian menunjukkan peningkatan $\mathrm{BB}$ dengan frekuensi $3 \times 15$ menit selama 10 hari, dengan rata-rata peningkatan 20 - 47\% (Proverawati, 2010) dan penelitian oleh (Gasma, 2016) dengan pijat bayi cara India/Swedia selama 30 hari dapat meningkatkan BB BBLR $50-65 \%$ pada umur 5 hari - 45 hari kehidupan golongan darah "O".

Hasil pijat memperlihatkan bahwa ratarata peningkatan $\mathrm{BB}$ lebih tinggi cara pijat Johnson jika dibandingkan dengan cara pijat India. Namun peningkatan BB tidak signifikan dengan uji statistik Mann-Withney U. Alasan penggunaan uji tersebut karena subyek kecil untuk uji komparasi.

Hasil penelitian tersebut sesuai dengan teori (Sari, 2020) yang menjelaskan bahwa Beta Endorphin yang mempengaruhi mekanisme pertumbuhan, penelitian mengungkapkan bahwa pijatan akan meningkatkan pertumbuhan dan perkembangan anak. Tahun 1989, Scanberg dari University Medical School melakukan penelitian pada bayi-bayi tikus. Pakar ini menemukan bahwa jika hubungan taktil (jilatan-jilatan) ibu tikus ke bayinya terganggu akan menyebabkan penurunan enzim ODC (Ornithine Decarboxylase) suatu enzim yang menjadi petunjuk bagi pertumbuhan sel dan jaringan, penurunan pengeluaran hormon pertumbuhan. Pengurangan sensasi taktil akan meningkatkan pengeluaran satu neurochemical beta-endorphine, yang akan mengurangi pembentukan hormon pertumbuhan karena menurunnya jumlah dan aktivitas ODC jaringan (Utami, 2009).

Aktivitas Nervus mempengaruhi mekanisme penyerapan makanan, penelitian (Field et al., 2012) menunjukkan bahwa pada bayi yang dipijat mengalami peningkatan tonus nervus vagus yang akan menyebabkan peningkatan enzim penyerapan gastrin dan insulin sehingga menyebabkan penyerapan makanan menjadi lebih baik dan meningkatkan berat badan bayi. Aktivitas Nervus Vagus meningkatkan volume ASI, penyerapan makanan menjadi lebih baik karena peningkatan aktivitas nervus vagus menyebabkan bayi cepat lapar dan akan lebih sering menyusu pada ibunya sehingga ASI akan lebih banyak diproduksi.

Variasi peningkatan BB subyek sangat tergantung dari berbagai faktor, yaitu kualitas makanan yang dikonsumsi, pengaruh psikologis. Pengaruh tersebut akan mempengaruhi produksi dan kualitas ASI ibu, sebagai sumber nutrisi bayi.

Pada penelitian tersebut, ditemukan bahwa ketika bayi sedang dipijat, maka dia merasa nyaman dan menjelang 12 menit pemijatan, sudah mulai menguap karena mengantuk. Kemudian ketika bayi dimandikan, maka dia akan menangis karena selain respon dingin, juga karena sudah haus. Respon haus tersebut ditunjukkan bahwa hasil pijatan memberikan respon positif terhadap fisiologi tubuh, yaitu akan segera menyusui dengan lahap karena haus dan tertidur pulas. Pada saat mulut bayi sudah tersentuh dengan puting susu maka mata segera tertutup sambil mengisap dengan lahap.

Hasil penelitian tersebut sesuai dengan teori dalam penelitian (Korompis \& Pesik, 
2018) yang menjelaskan bahwa produksi Serotonin meningkatkan daya tahan tubuh, pemijatan akan meningkatkan aktivitas neurotransmitter serotonin yang meningkatkan kapasitas sel reseptor untuk mengikat glukokortiroid (adrenalin suatu hormon stres) sehingga menyebabkan terjadinya penurunan kadar hormon adrenalin dan meningkatkan daya tahan tubuh terutama IgM dan IgG. Pijatan dapat mengubah gelombang otak, pijat bayi akan membuat bayi tidur lebih lelap dan meningkatkan kesiagaan (allertness) atau konsentrasi karena pijatan dapat mengubah gelombang otak dengan cara menurunkan gelombang beta serta tetha yang dapat dibuktikan dengan penggunaan EEG (Electro Enchephalogram) (Suprihatini, K. et al., 2014).

Hasil observasi, bahwa dengan pijat bayi maka akan memberi respon positif terhadap fisik maupun psikologis bayi, yang dapat meningkatkan kualitas hidup bayi dengan BBLR. Keberhasilan mempertahankan kualitas BBLR, tidak cukup dengan hanya menitik beratkan kepada ibu dan cara ibu merawat tanpa dukungan yang besar oleh pendamping yaitu suami dan keluarga. Dukungan suami sangat diharapkan khususnya dukungan psikologis dan dukungan sosial ekonomi.

Subyek penelitian, merupakan penduduk dengan ekonomi menengah ke bawah dan tinggal pada daerah pemukiman yang padat penduduknya. Dalam hal ini yang perlu mendapat perhatian adalah tingkat pendidikan dan status sosial ekonomi. Pada umumnya penyebab Bayi berat lahir rendah adalah dari kalangan keluarga dengan taraf pendidikan yang masih rendah, serta penghasilan yang di bawah rata-rata. Perbedaan peningkatan $\mathrm{BB}$ BBLR, juga dipengaruhi oleh apa yang menjadi konsumsi sehari-hari oleh ibunya, tergantung oleh kualitas makanan yang dikonsumsi yang menjadi konsumsi bayi yaitu melalui ASI. Respon dari hasil pijat adalah peningkatan frekuensi menyusui dan bayi lahap. Jika bayi telah dipijat maka respon tersebut akan disalurkan melalui menyusu. Namun tidak semua bayi dapat menerima kualitas ASI yang diharapkan, akibat dari penghasilan orang tua yang tidak mencukupi.

\section{KESIMPULAN DAN SARAN}

Kesimpulan penelitian bahwa pijat bayi cara India dan Johnson keduanya meningkatkan berat badan BBLR. Dapat dilakukan penelitian lanjutan untuk melihat pengaruh pijat bayi cara India dan Johnson terhadap pertambahan tinggi badan.

\section{DAFTAR PUSTAKA}

BPS. (2020). Jumlah Kematian Balita Menurut Kelompok Umur. Databoks. Katadata.co.id. https://databoks.katadata. co.id/datapublish/2021/10/22/ kematianbalita-di-indonesia-capai- 282-ribu-pada2020.

Field, T., Diego, M., Hernandez-Reif, M., Medina, L., Delgado, J., \& Hernandez, A. (2012). Yoga and massage therapy reduce prenatal depression and prematurity. Journal of Bodywork and Movement Therapies, 16(2), 204-209. https://doi.org/10.1016/j.jbmt.2011.08.002

Gasma, A. (2016). Pengaruh Pijat Bayi terhadap peningkatan berat badan BBLR Golongan darah O. Prosiding Hasil Penelitian Interprofesi Kesehatan Poltekkes Kemenkes 2016.

Korompis, M., \& Pesik, D. M. D. (2018). Pentingnya Pijat Pada 1000 Hari Pertama Kehidupan Anak. PROSIDING Seminar Nasional, 1(3), 516-524. https://ejurnal.poltekkes-manado. ac.id/ index.php/prosiding2018/article/view/450.

Proverawati, A. (2010). Berat Badan Lahir Rendah (BBLR. Nuha Medika.

Sari, N. J. P. (2020). Pengaruh Pijat Bayi Terhadap Pertumbuhan Bayi Umur 5-6 Bulan Di Desa Rimbo Panjang [Poltekkes Kemenkes Riau]. http://repository. pkr.ac.id/593/.

Sastroasmoro, S., \& Ismael, S. (2016). Dasardasar metodologi penelitian klinis. Sagung Seto.

Suprihatini, K., Widyawati, M. N., \& Sutarmi. (2014). Modul Pelatihan Touch Training: Pediatric Massage Therapy.

Utami, R. (2009). Pedoman Pijat Bayi Prematur dan Bayi Usia 0-3 Bulan. Pustaka Pembangunan Swadaya Nusantara. 